\section{CONTENTS}

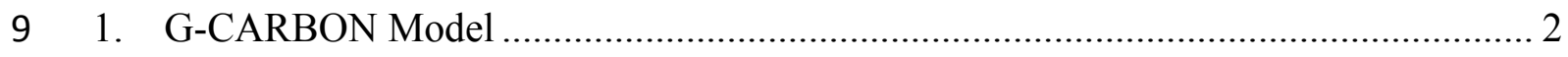

\title{
Carbon Density and Anthropogenic Land Use Influences on Net Land-Use Change Emissions
}

Supplementary Material

\author{
Steven J. Smith and Andrew Rothwell \\ Joint Global Change Research Institute \\ Pacific Northwest National Laboratory, College Park, MD
}

1.1. G-CARBON Model Parameters ....................................................................... 2

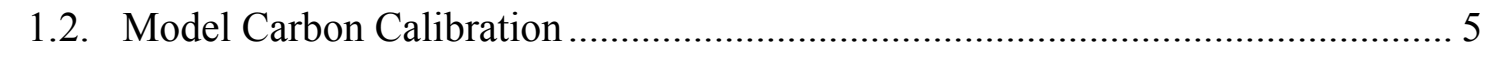

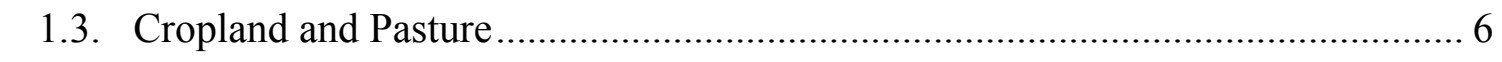

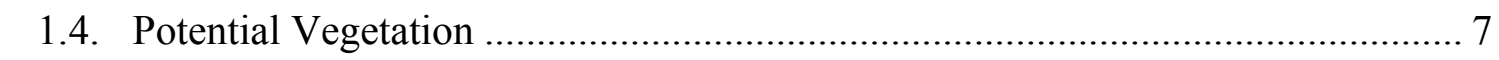

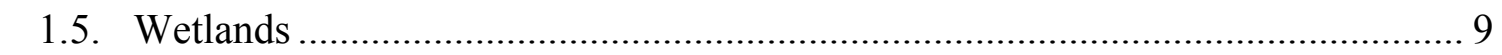

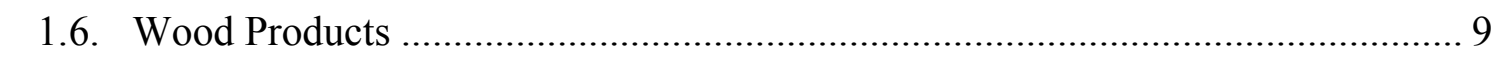

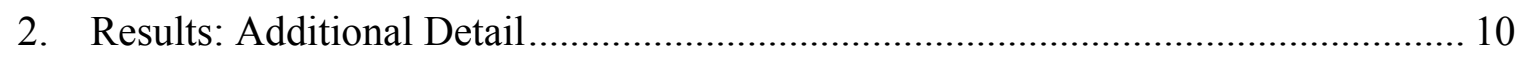

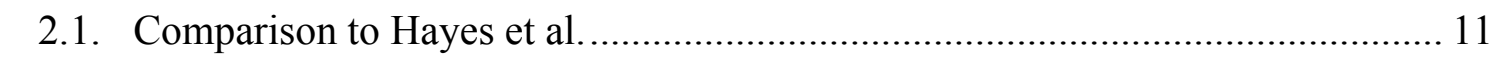

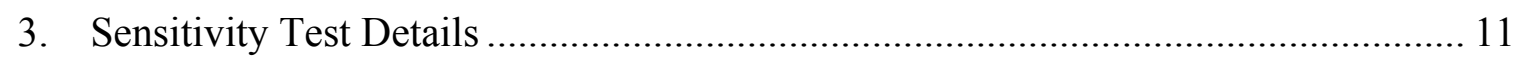

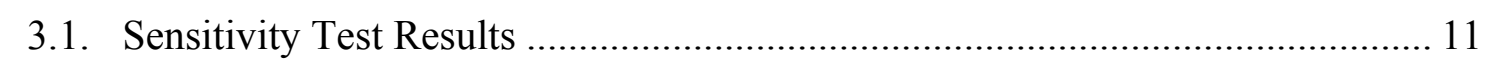

3.2. NPP and Carbon Values for Sensitivity Tests ............................................... 14

3.3. Land-Use Change Carbon Disturbance ........................................................ 16

3.4. Carbon Box Turnover-Time Sensitivities..................................................... 17

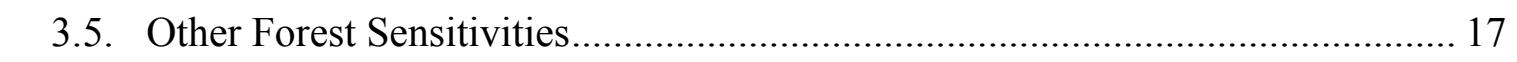

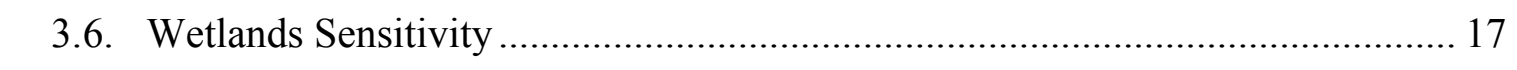

3.7. Temperature And Carbon Dioxide Feedback .................................................. 18

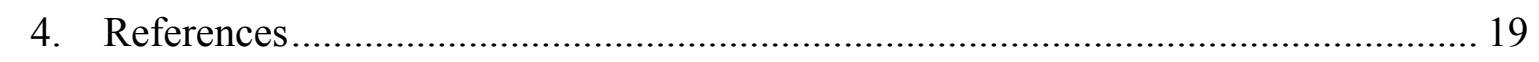




\section{1. G-CARBON Model}

\section{1.1. G-CARBON Model Parameters}

3 Annual net carbon flow coefficients, $a_{i}^{j}$ in Equations 1-3 (main text), are given in the

4 following table.

\begin{tabular}{|c|c|c|c|c|c|c|c|c|c|}
\hline Original carbon box & NPP & NPP & NPP & veg & veg & veg & litter & litter & soil \\
\hline Destination carbon box & veg & litter & soil & litter & soil & atm & soil & atm & atm \\
\hline Primary non-boreal forest & \multirow{3}{*}{\multicolumn{3}{|c|}{ vary by region }} & $94 \%$ & $6 \%$ & $0 \%$ & $6 \%$ & $94 \%$ & $100 \%$ \\
\hline Secondary non-boreal forest & & & & $94 \%$ & $6 \%$ & $0 \%$ & $6 \%$ & $94 \%$ & $100 \%$ \\
\hline Boreal forest & & & & $94 \%$ & $6 \%$ & $0 \%$ & $6 \%$ & $94 \%$ & $100 \%$ \\
\hline Cropland & $20 \%$ & $65 \%$ & $15 \%$ & $88 \%$ & $12 \%$ & $0 \%$ & $10 \%$ & $90 \%$ & $100 \%$ \\
\hline Pasture & $35 \%$ & $60 \%$ & $5 \%$ & $67 \%$ & $33 \%$ & $0 \%$ & $6 \%$ & $94 \%$ & $100 \%$ \\
\hline Grassland & $35 \%$ & $60 \%$ & $5 \%$ & $67 \%$ & $33 \%$ & $0 \%$ & $6 \%$ & $94 \%$ & $100 \%$ \\
\hline Shrubland & $35 \%$ & $60 \%$ & $5 \%$ & $67 \%$ & $33 \%$ & $0 \%$ & $6 \%$ & $94 \%$ & $100 \%$ \\
\hline Tundra & $35 \%$ & $60 \%$ & $5 \%$ & $67 \%$ & $33 \%$ & $0 \%$ & $6 \%$ & $94 \%$ & $100 \%$ \\
\hline Rock, ice, \& desert & $35 \%$ & $60 \%$ & $5 \%$ & $67 \%$ & $33 \%$ & $0 \%$ & $6 \%$ & $94 \%$ & $100 \%$ \\
\hline Urbanland & $35 \%$ & $60 \%$ & $5 \%$ & $67 \%$ & $33 \%$ & $0 \%$ & $6 \%$ & $94 \%$ & $100 \%$ \\
\hline High latitude wetland/peatland & $35 \%$ & $60 \%$ & $5 \%$ & $67 \%$ & $33 \%$ & $0 \%$ & $6 \%$ & $94 \%$ & $100 \%$ \\
\hline Mid \& low latitude wetland & $35 \%$ & $60 \%$ & $5 \%$ & $67 \%$ & $33 \%$ & $0 \%$ & $6 \%$ & $94 \%$ & $100 \%$ \\
\hline
\end{tabular}

Table SM-1. Carbon flow coefficients, $a_{i}^{j}$, as in Equations 1-3 main text.

The coefficient values in Table SM-1 represent a simplified representation of vegetation growth. We first discuss values for non-forest ecosystems. Note that, because this model runs with an annual time-step, some portion of NPP, which over a short timescale flows to vegetation, is transferred over the annual period of this model to litter (and a small portion to soil). The NPP flow coefficients are taken to be those of Wigley (1993). Values used here for non-forest ecosystems are largely from Harvey (1989), which draw from the work of Emanuel et al. (1984), using values for ground vegetation. As described below, carbon density values are then used to calibrate the remaining parameter, which are the turnover timescales, $\tau_{i}$.

For boreal and non-boreal forests, the annual NPP flow fractions are determined in each region by setting the vegetation turnover timescale to match the general values given in Houghton and Hackler (1995) of 65, 50, and 30 years for boreal, temperate, and tropical forests, respectively. Forest vegetation flow fractions use the values for woody vegetation from Harvey (1989), again based on Emanuel et al. (1984).

Carbon flows from vegetation to litter and soil for cropland are increased, given that much of the vegetation is comprised of harvested products that are removed from the field. This assumptions has little impact on the results, however, since most of the carbon in cropland is contained in the soil.

The values for these flows are not well constrained, however. Summaries at this level of aggregation, of either observational or model studies, are rarely provided. When the 
sensitivities to these values are examined (Table SM-10), we find relatively low sensitivities to most of these carbon box flow fractions. Note that some of the sensitivity cases are unrealistic, for example $100 \%$ of forest NPP flow to vegetation (averaged over a year), but serve to examine the impact of uncertainty in these parameters. The main reason the uncertainty in these parameters is relatively low is that we calibrate the model to equilibrium carbon stocks. With turnover timescales adjusted to achieve the same equilibrium carbon stock values, land-use change emissions are not strongly impacted by changes in flow values. We note that decreasing the fraction of cropland "effective NPP" that flows to litter (which increases the flow to soils) increases $21^{\text {st }}$ century uptake by $10 \%$. This points to a need to better characterize future cropland carbon dynamics.

A second set of flow parameters (Table SM-2) describe carbon flows during land-use change. Aggregate land-transfers are tracked for each region. These carbon flows are accounted for as follows. If, during a timestep, area in an ecosystem is decreased, then all carbon pools in that carbon box model are proportionately decreased. The aggregate amount of carbon in areas that transition to new ecosystem types is re-apportioned to ecosystem types within that region that gain land during that time step.

Carbon flows due to LUC in the central scenario, represented by $f_{i}(L U C)$ in Equation 1 , are given in the following table. Destination marked "stay" indicates the fraction of carbon that was assumed to remain in the same carbon pool, albeit assigned to the destination ecosystem. Some of the carbon in any pool can also be assigned to be transferred to another carbon pool. A fraction of the total carbon in each pool denoted as "atm" in Table SM-2 is assumed to flow immediately to the atmosphere as carbon dioxide. As discussed in the text, these flows, including emissions to the atmosphere, represent carbon flows associated with the process of land-use change. Examples include burning of vegetation during clearing (which would result primarily in emissions to the atmosphere), cutting of vegetation (which might result in some near-term transfer of vegetation carbon to litter), or disturbance of the soil (which would result in some loss of soil carbon through respiration). While the model operates on an annual timestep, LUC flows could, in reality, operate over a somewhat longer period.

Immediate LUC emissions are assigned to the ecosystem losing land, and delayed LUC emissions (litter decay and non-immediate soil changes) are assigned as emissions from the new ecosystem. This procedure efficiently approximates the carbon flows that would occur under a more spatially explicit carbon model. Total carbon, including amounts transferred to or from the atmosphere, is preserved within each model region.

When forest is converted to cropland, for example, most of the above ground carbon is assumed to be lost to the atmosphere, although some could be transferred to other carbon pools. The majority of soil carbon is assumed to stay in the soil.

There is little research from which to choose the values of these flows. Nearly all of the literature on land-use change focuses on the change in total carbon density from a pre-change state to a state measured in the final ecosystem, generally some years after the transformation. Here, in contrast, we have partitioned this change into two parts: shortterm and long-term, where the longer-term portion of the change is represented a relaxation toward the equilibrium state of the ecosystem that gains land. Literature 
1 reviews on this subject do not, in general, distinguish between short-term and long-term 2 dynamics. One exception is cropland, see below.

3 We choose, therefore, conservative values to represent short-term LUC dynamics. In 4 general, most processes that convert forested ecosystem to other land uses removes 5 nearly all vegetation carbon. So we assume most of this vegetation carbon is transferred 6 to the atmosphere. Similarly for litter. The sensitivity tests presented later in this work 7 (Table SM-10), find that results are minimally impacted by changes in these parameters. 8 We note that the values in Table SM-2 apply to all changes where land-use associated 9 with a particular ecosystem changes, regardless of the destination ecosystem. This is due 10 to a limitation in the current model code. So these values represent the average value for 11 all the different types of transition that occur (for example: forest to secondary forest; 12 forest to pasture, or forest to cropland).

13 Results are somewhat more sensitive to the assumed short-term release of carbon 14 from soil ecosystems. In general, most land-use transitions do not involve large physical 15 disruptions to soil. Changes to vegetation, such as deforestation, however mean that 16 many existing root structures will decay, presumably involving changes to microbial 17 communities as well. Conversion to cropland has been the focus of much research. 18 Reviews of this literature indicate that approximately $30 \%$ of soil carbon is lost over a 19 relatively short period of time during conversion to cropland (Murty et al. 2002, Guo \& 20 Gifford 2002, Luo et al. 2010, Don et al. 2011). The values below are much smaller than 21 this value since the model cannot currently distinguish between conversion to cropland 22 and conversion to other ecosystems. Initial soil carbon values in cropland are, therefore, 23 overestimated in the current model. In part, however, this means that emissions that 24 should happen in the near-term, will actually happen instead over the longer-term as the 25 cropland soil carbon pool comes into equilibrium (particularly for conversion to cropland 26 before the mid- $20^{\text {th }}$ century "green revolution"). This likely contributes some bias to 27 cropland carbon contents, although the overall impact at a global or regional scale when 28 averaged over many decades is likely small. Cropland carbon dynamics are explored in 29 separate work (Smith 2013).

30 


\begin{tabular}{|l|c|c|c|c|c|c|c|c|}
\hline Original carbon box & veg & veg & veg & litter & litter & litter & soil & soil \\
\hline Destination carbon box & atm & litter & soil & stay & soil & atm & stay & atm \\
\hline Primary non-boreal forest & $78 \%$ & $20 \%$ & $2 \%$ & $25 \%$ & $0 \%$ & $75 \%$ & $95 \%$ & $5 \%$ \\
\hline Secondary non-boreal forest & $78 \%$ & $20 \%$ & $2 \%$ & $25 \%$ & $0 \%$ & $75 \%$ & $95 \%$ & $5 \%$ \\
\hline Boreal forest & $78 \%$ & $20 \%$ & $2 \%$ & $25 \%$ & $0 \%$ & $75 \%$ & $95 \%$ & $5 \%$ \\
\hline Cropland & $80 \%$ & $18 \%$ & $2 \%$ & $100 \%$ & $0 \%$ & $0 \%$ & $100 \%$ & $0 \%$ \\
\hline Pasture & $80 \%$ & $18 \%$ & $2 \%$ & $100 \%$ & $0 \%$ & $0 \%$ & $100 \%$ & $0 \%$ \\
\hline Grassland & $80 \%$ & $18 \%$ & $2 \%$ & $25 \%$ & $0 \%$ & $75 \%$ & $95 \%$ & $5 \%$ \\
\hline Shrubland & $80 \%$ & $18 \%$ & $2 \%$ & $25 \%$ & $0 \%$ & $75 \%$ & $95 \%$ & $5 \%$ \\
\hline Tundra & $80 \%$ & $18 \%$ & $2 \%$ & $25 \%$ & $0 \%$ & $75 \%$ & $95 \%$ & $5 \%$ \\
\hline Rock, ice, \& desert & $80 \%$ & $18 \%$ & $2 \%$ & $25 \%$ & $0 \%$ & $75 \%$ & $95 \%$ & $5 \%$ \\
\hline Urbanland & $80 \%$ & $18 \%$ & $2 \%$ & $25 \%$ & $0 \%$ & $75 \%$ & $95 \%$ & $5 \%$ \\
\hline High latitude wetland/peatland & $80 \%$ & $18 \%$ & $2 \%$ & $25 \%$ & $0 \%$ & $75 \%$ & $95 \%$ & $5 \%$ \\
\hline Mid \& low latitude wetland & $80 \%$ & $18 \%$ & $2 \%$ & $25 \%$ & $0 \%$ & $75 \%$ & $95 \%$ & $5 \%$ \\
\hline
\end{tabular}

Table SM-2. Coefficients specifying the disposition of carbon under land-use change.

\subsection{Model Carbon Calibration}

ISAM forest vegetation carbon densities were assumed to include dead wood; FAO data providing vegetation and deadwood carbon densities for each region was used to adjust the ISAM values to remove deadwood. FAO litter-to-vegetation ratios were used to calculate litter carbon densities from the adjusted vegetation values, and the deadwood carbon was added to the litter pool.

Litter carbon density values for grassland and shrubland were set to be $10 \%$ of the soil values of each ecosystem. Grassland vegetation density values were set to be $33 \%$ of the litter values. These values are small and have little impact on the results.

Wetland ecosystems were assumed to have a NPP value of $0.25 \mathrm{kgC} / \mathrm{m}^{2} / \mathrm{yr}$ (Blodau 2002). Wetland vegetation and soil carbon density values are from Bridgham et al. (2007). For tundra, global values for NPP, vegetation, and soil, from Table 1 of Jain and Yang (2005), were used for all regions. Because litter carbon is not accounted for in these tables, the regional litter values of shrubland were used as litter values for all wetlands and tundra; in each region the soil values were reduced by the amounts attributed to litter. Because wetland ecosystems are currently still carbon-sinks, soil turnover timescales were set such that wetlands have a net sequestration of $0.015 \mathrm{~kg} \mathrm{C} / \mathrm{m}^{2}$ per year (Bridgham et al., 2007) in 1500 .

Wetlands are, therefore, the only ecosystem that is not assumed to be in equilibrium in 1500. Because we define LUC emissions as the anthropogenic perturbation, wetland uptake that would have taken place in the absence of land-use change (which declines from 6 to $5 \mathrm{GtC} /$ century) is not included in the LUC estimates reported in this paper.

For NPP for rock, ice, and desert areas, and for urbanland, data from the NASACarnegie-Ames-Stanford Approach (CASA) Project was used (Potter, 2012). For the 
vegetation and soil boxes, values used in the GCAM model were used; for rock, ice, and desert, from Table 3 of King et al. (1997), adjusted for each region. Litter values in both land-uses were set based on the ratio of litter to soil of the same land-uses in the NASACASA data.

\subsection{Cropland and Pasture}

Representing cropland requires an estimate of the area of land actually planted in crops along with the productivity of those crops. Total cropland areas from Hurtt et al. (2011) represent reported arable land, which is larger than harvested crop area. The difference can be due to areas of: fallow land, conservation reserves, failed crops, and land temporarily used for other purposes.

Harvested crop areas for recent decades are obtained from FAO data, adjusted for double cropping using the GCAM data processing methodology (Kyle et al., 2011). For the future, harvested areas were estimated made by scaling FAO 2005 data by the trend in cropland area in the GCAM 4.5 scenario. Harvested area in the past is obtained from the data sources described below. Other arable land is estimated by subtracting the harvested area from the total cropland areas from by Hurtt et al. For other arable land in the future, the 2005 value is adjusted by the trend in other arable land area in the GCAM 4.5 scenario.

For recent years, crop NPP values are calculated from harvest data using the methods of Hicke and Lobell (2004) as implemented in GCAM (Kyle et al., 2011). Regional values were calculated for years centered on 1962, 1970, 1980, 1990, 2000, and 2005, based on harvest data from the Food and Agriculture Organization (FAO) of the United Nations ("FAOSTAT Production," 2012). Values were also estimated for the years 1950, 1940, 1900, and 1870 (where available) based on harvest data from various data sources (Mitchell, 1975, 1988, 2007a, 2007b, 2007c; Trant 1999; USDA NASS). In all cases, the aggregate cropland NPP value is the production-weighted average across crop categories.

The equilibrium soil and litter carbon values for harvested cropland in 2005 are taken from Thomson et al. (2008); with litter apportioned as 3-15\% of the carbon, based on regional conditions. For vegetation, present day carbon densities were obtained from Table 1 of Houghton (1999), as used in GCAM (Kyle et al., 2011). Equilibrium cropland carbon values for the 1870 starting point were estimated by scaling the 2005 values based on the relative magnitude of the change in NPP between 1870 and 2005. Turnover timescales were assumed to have been lower in the past, and to have increased from 1940 to 1960 by $20 \%$ due to general improvements in tillage practices.

The values above are applied to the harvested cropland area. Regional grassland values are used for other arable land. The area-weighted combination is used for the total cropland area (which consists of harvested cropland + other arable land) in the carbon model. 
1 The regional trends in cropland effective NPP are given in the following table. Note

2 that NPP trends reflect the combination of changes in productivity and changes in crop

3 mix.

\begin{tabular}{|c|c|c|c|c|c|c|c|c|c|c|c|c|c|c|}
\hline Year & Africa & Australia_NZ & Canada & China & $\begin{array}{l}\text { Eastern } \\
\text { Europe }\end{array}$ & \begin{tabular}{|l} 
Former \\
Soviet \\
Union
\end{tabular} & India & Japan & Korea & $\begin{array}{l}\text { Latin } \\
\text { America }\end{array}$ & $\begin{array}{l}\text { Middl } \\
\text { East }\end{array}$ & $\begin{array}{l}\text { Southea } \\
\text { Asia }\end{array}$ & USA & $\begin{array}{l}\text { Western } \\
\text { Europe }\end{array}$ \\
\hline 1870 & 1.00 & 1.00 & 1.00 & 1.00 & 1.00 & 1.00 & 1.00 & 1.00 & 1.00 & 1.00 & 1.00 & 1.00 & 1.00 & 1.00 \\
\hline 1900 & 1.00 & 0.83 & 0.98 & 1.00 & 1.00 & 1.38 & 1.00 & 1.00 & 1.00 & 1.00 & 1.00 & 1.00 & 0.92 & 0.80 \\
\hline 1940 & 1.00 & 1.18 & 0.91 & 1.00 & 0.90 & 1.39 & 0.74 & 0.90 & 1.00 & 1.00 & 1.00 & 1.00 & 1.00 & 0.96 \\
\hline 1950 & 0.71 & 1.27 & 0.91 & 0.83 & 0.79 & 1.59 & 0.65 & 0.74 & 1.01 & 1.21 & 0.86 & 0.91 & 1.02 & 1.07 \\
\hline 1962 & 0.94 & 1.26 & 0.87 & 0.67 & 1.13 & 1.42 & 0.66 & 0.81 & 1.05 & 1.18 & 0.82 & 0.95 & 1.13 & 1.09 \\
\hline 1970 & 0.85 & 1.22 & 0.89 & 0.90 & 1.55 & 1.68 & 0.66 & 0.85 & 1.07 & 1.23 & 0.77 & 0.95 & 1.21 & 1.16 \\
\hline 1980 & 0.96 & 1.14 & 0.84 & 1.12 & 1.77 & 1.66 & 0.66 & 0.79 & 1.24 & 1.28 & 0.70 & 1.03 & 1.18 & 1.16 \\
\hline 1990 & 0.81 & 1.22 & 0.82 & 1.32 & 1.80 & 1.92 & 0.72 & 0.83 & 1.32 & 1.34 & 0.68 & 1.15 & 1.33 & 1.20 \\
\hline 2000 & 0.79 & 1.21 & 0.87 & 1.40 & 1.79 & 1.92 & 0.80 & 0.78 & 1.23 & 1.42 & 0.71 & 1.34 & 1.38 & 1.29 \\
\hline 2005 & 0.84 & 1.19 & 0.89 & 1.40 & 1.84 & 2.24 & 0.83 & 0.77 & 1.14 & 1.54 & 0.83 & 1.52 & 1.42 & 1.30 \\
\hline 2020 & 0.92 & 1.16 & 0.79 & 1.60 & 1.86 & 2.13 & 0.92 & 0.77 & 1.14 & 1.86 & 0.86 & 1.93 & 1.47 & 1.35 \\
\hline 2035 & 0.93 & 1.01 & 0.84 & 1.60 & 1.74 & 2.02 & 1.05 & 0.74 & 1.14 & 1.98 & 0.91 & 2.41 & 1.45 & 1.38 \\
\hline 2050 & 0.95 & 0.99 & 0.88 & 1.55 & 1.62 & 2.15 & 1.10 & 0.69 & 1.13 & 2.03 & 0.90 & 2.50 & 1.44 & 1.39 \\
\hline 2065 & 0.95 & 1.00 & 0.92 & 1.57 & 1.60 & 2.14 & 1.09 & 0.66 & 1.12 & 2.05 & 0.90 & 2.52 & 1.49 & 1.41 \\
\hline 2080 & 0.96 & 1.02 & 0.96 & 1.62 & 1.62 & 2.11 & 1.05 & 0.65 & 1.14 & 2.06 & 0.91 & 2.52 & 1.58 & 1.45 \\
\hline 2095 & 0.97 & 1.04 & 1.00 & 1.68 & 1.67 & 2.11 & 1.04 & 0.67 & 1.19 & 2.05 & 0.93 & 2.52 & 1.66 & 1.51 \\
\hline 2100 & 0.97 & 1.04 & 1.01 & 1.70 & 1.69 & 2.11 & 1.04 & 0.68 & 1.20 & 2.05 & 0.93 & 2.52 & 1.68 & 1.52 \\
\hline
\end{tabular}

4 Table SM-3. Cropland effective NPP trends (normalized to the earliest value for each 5 region).

\subsection{Potential Vegetation}

8 The SAGE global potential vegetation dataset is reclassified to G-CARBON 9 ecosystems using the reclassification system shown in the following table:

\begin{tabular}{|l|l|}
\hline \multicolumn{1}{|c|}{ SAGE Potential Vegetation Type } & \multicolumn{1}{c|}{ G-CARBON Ecosystem } \\
\hline Tropical Evergreen Forest/Woodland & Non-boreal Forest \\
\hline Tropical Deciduous Forest/Woodland & Non-boreal Forest \\
\hline Temperate Broadleaf Evergreen Forest/Woodland & Non-boreal Forest \\
\hline Temperate Needleleaf Evergreen Forest/Woodland & Non-boreal Forest \\
\hline Temperate Deciduous Forest/Woodland & Non-boreal Forest \\
\hline Boreal Evergreen Forest/Woodland & Boreal Forest \\
\hline Boreal Deciduous Forest/Woodland & Boreal Forest \\
\hline Evergreen/Deciduous Mixed Forest & MODIS reclassification \\
\hline Savanna & Grassland \\
\hline Grassland/Steppe & Grassland \\
\hline Dense Shrubland & Shrubland \\
\hline Open Shrubland & Shrubland \\
\hline Tundra & Tundra \\
\hline
\end{tabular}


Desert

Rock, Ice, \& Desert

Polar Desert/Rock/Ice

Rock, Ice, \& Desert

1 Table SM-4. Mapping between SAGE potential vegetation categories to the ecosystem

2 categories used in this work.

3

4 A large portion of high latitude areas, in particular, are classified as Mixed Forest in the

5 SAGE data. This results an unrealistically large amount of high latitude forests. Where

6 possible, the SAGE Evergreen/Deciduous Mixed Forest categories were replaced by the

7 following MODIS IGBP Land Cover Types, mapped to G-CARBON ecosystems as

8 follows:

9

\begin{tabular}{|l|l|}
\hline \multicolumn{1}{|c|}{ MODIS IGBP Land Cover Type } & \multicolumn{1}{c|}{ G-CARBON Ecosystem } \\
\hline Evergreen Needleleaf Forest & Boreal Forest \\
\hline Evergreen Broadleaf Forest & Non-boreal Forest \\
\hline Deciduous Needleleaf Forest & Boreal Forest \\
\hline Deciduous Broadleaf Forest & Non-boreal Forest \\
\hline Mixed Forests & Non-boreal Forest \\
\hline Closed Shrublands & Shrublands \\
\hline Open Shrublands & Shrublands \\
\hline Woody Savannas & Shrublands \\
\hline Savannas & Grassland \\
\hline Grasslands & Grassland \\
\hline Permanent Wetlands & High or Low Latitude Wetlands \\
\hline Croplands & Non-boreal Forest \\
\hline Urban and Built-up & Non-boreal Forest \\
\hline Cropland/Natural Vegetation Mosaic & Non-boreal Forest \\
\hline Snow and Ice & Rock, Ice, \& Desert \\
\hline Barren or Sparsely Vegetated & Rock, Ice, \& Desert \\
\hline
\end{tabular}

11 Table SM-5. Mapping between MODIS vegetation categories to the ecosystem categories 12 used in this work.

13

14 Note that three MODIS categories which are modern land uses (Croplands, Urban and 15 Built-up, and Cropland/Natural Vegetation Mosaic) are reclassified as Non-boreal Forest

16 for the G-CARBON ecosystem data (these are small, since this re-classification is only 17 being applied to SAGE areas classified as mixed forest). The MODIS category Mixed

18 Forests is reclassified as Non-boreal Forest. Note that there is a smaller area in the

19 MODIS data classified as mixed forest as compared to the SAGE data. 
2 In order to estimate the location and extent of wetlands, the Global Lakes and Wetlands

3 Database (GLWD) data was compared to SAGE at $5 \mathrm{~min}$ resolution. For any cell

4 classified as 100\% wetlands in the GLWD, corresponding cells in the SAGE dataset that

5 were classified as Mixed Forest, Shrubland, Grassland, and Rock, Ice, and Desert were

6 re-classified as Wetlands. For any cell classified as $<100 \%$ wetlands, this percentage is

7 used to replace that percentage of all ecosystem types in the SAGE data. This procedure

8 yields 447 million ha of global wetlands in 2000. The resulting estimate of wetland areas

9 in the USA in 2000 (79 million ha) is slightly lower than the area given in the first State

10 of the Carbon Cycle Report (SOCCR) (112 million ha), while the Canada estimate (131

11 million ha) matches SOCCR exactly (King et al. 2007). We recognize that these

12 estimates are quite uncertain, but given the importance of wetlands to regional and global

13 carbon-cycle, we feel this procedure provides a reasonable estimate.

$14 \quad$ 1.6. Wood Products

15 Total wood product production was split into the following categories (Winjum et al.

16 1998, Buchanan \& Levine 1999).

17

\begin{tabular}{llr} 
Commodity & Term & Fraction \\
\hline SawnWood & long-term & 0.12 \\
PaperPulpwood & long-term & 0.09 \\
OtherRoundwood & long-term & 0.05 \\
ShortTerm & short-term & 0.74
\end{tabular}

18 Table SM-6. Assumed disposition of wood products.

19

20 Where the short-term product pool is a generic category for both products and waste that

21 is assumed to quickly decay to the atmosphere.

23 The turnover timescale is assumed to vary regionally by product pool as follows (Winjum

24 et al. 1998):

25

Turnover-timescale (yr)

\begin{tabular}{llrrr} 
& & \multicolumn{3}{c}{ Forest Region } \\
Commodity & Term & Boreal & Temperate & Tropical \\
\hline SawnWood & long-term & 200 & 100 & 50 \\
PaperPulpwood & long-term & 200 & 100 & 10 \\
OtherRoundwood & long-term & 50 & 25 & 12.5 \\
ShortTermRoundwood & short-term & 0.5 & 0.5 & 0.5
\end{tabular}

26 Table SM-7. Assumed turnover timescales for wood products. 


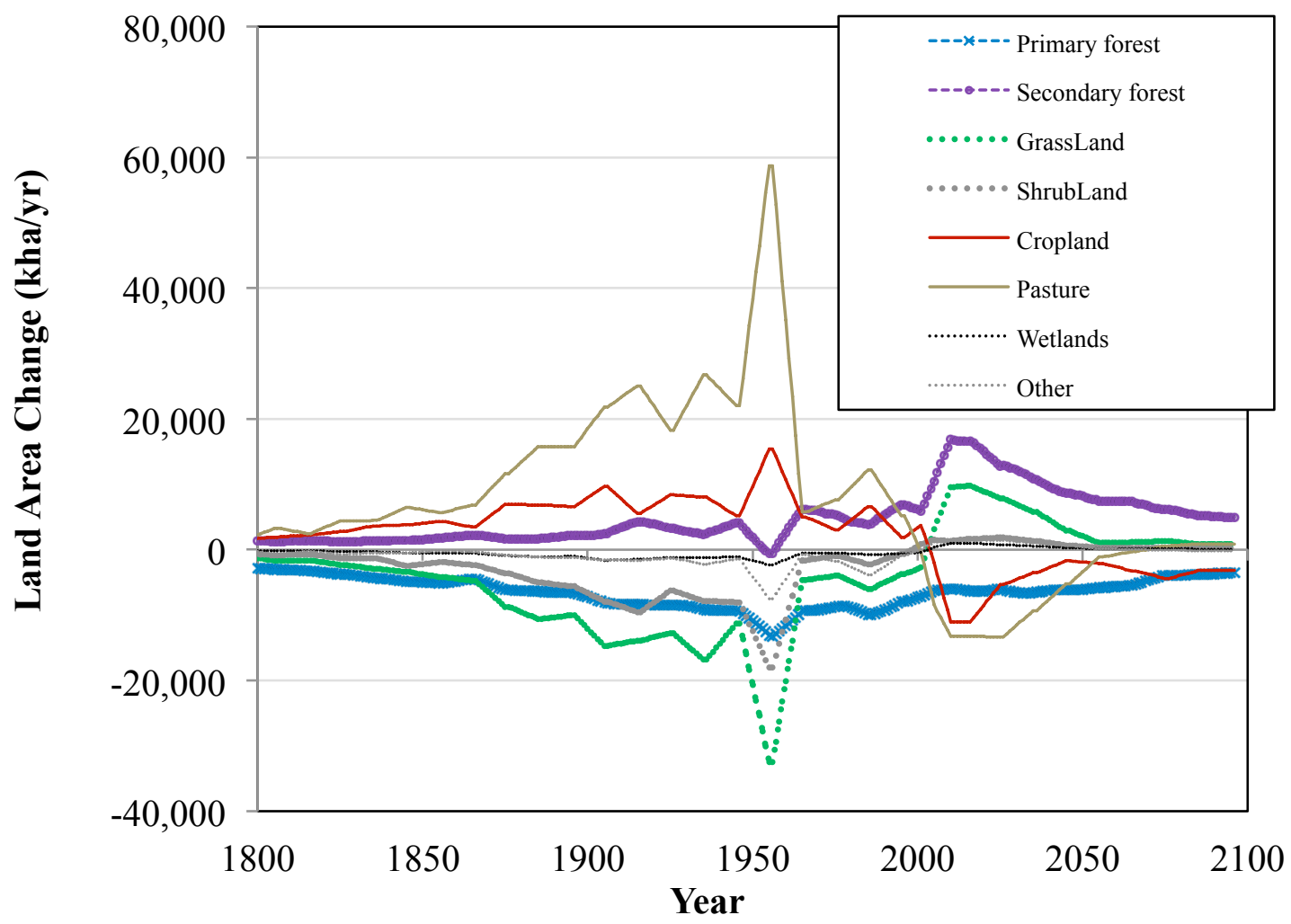

Figure SM-1. Annual global land area changes (kha/yr) by ecosystem (smoothed by 9 year averaging).

\begin{tabular}{|l|c|c|c|c|c|}
\hline \multirow{2}{*}{ Land-Use } & $\begin{array}{c}\text { Total } \\
\mathbf{1 7 0 0}- \\
\mathbf{2 0 0 0}\end{array}$ & $\begin{array}{c}\text { Total } \\
\mathbf{1 8 5 0 -} \\
\mathbf{2 0 0 0}\end{array}$ & $\begin{array}{c}\text { Total } \\
\mathbf{2 0 0 0}- \\
\mathbf{2 1 0 0}\end{array}$ & $\begin{array}{c}\text { Average } \\
\mathbf{1 9 8 0 -} \\
\mathbf{1 9 8 9}\end{array}$ & $\begin{array}{c}\text { Average } \\
\mathbf{1 9 9 0 -} \\
\mathbf{1 9 9 9}\end{array}$ \\
\hline Primary non-boreal forest & $-1,653.6$ & $-1,217.7$ & -546.4 & -9.7 & -8.2 \\
\hline Secondary non-boreal forest & 678.3 & 475.9 & 916.6 & 4.0 & 6.6 \\
\hline Grassland & $-1,809.6$ & $-1,590.2$ & 347.9 & -5.8 & -4.0 \\
\hline Shrubland & -933.8 & -817.3 & 81.6 & -2.1 & -0.8 \\
\hline Cropland & $1,231.7$ & 973.1 & -405.2 & 6.3 & 2.4 \\
\hline Pasture & $2,995.7$ & $2,596.7$ & -487.4 & 11.8 & 5.9 \\
\hline High latitude wetland/peatland & -19.5 & -18.3 & 9.8 & -0.1 & -0.2 \\
\hline Mid \& low latitude wetland & -161.0 & -136.4 & 27.0 & -0.7 & -0.5 \\
\hline Boreal forest & -31.4 & -26.2 & 20.2 & 0.0 & -0.4 \\
\hline Tundra & -132.0 & -104.1 & 28.4 & -2.3 & -0.5 \\
\hline Rock, Ice, \& Desert & -217.0 & -183.4 & 1.5 & -2.1 & -1.2 \\
\hline Urbanland & 52.2 & 48.0 & 5.9 & 0.7 & 0.9 \\
\hline
\end{tabular}


1 Table SM-8. Net global land area changes (1000 kha) by ecosystem.

\subsection{Comparison to Hayes et al.}

4

Average annual total NEE (Hayes et al., 2011) and net land-use change emissions for 5 the USA and Canada (MtC/year).

6

\begin{tabular}{|l|c|c|c|c|}
\hline & \multicolumn{2}{|c|}{ USA } & \multicolumn{2}{c|}{ Canada } \\
\hline Ecosystem & $\begin{array}{c}\text { Hayes et } \\
\text { al. (2011) }\end{array}$ & G-CARBON & $\begin{array}{c}\text { Hayes et } \\
\text { al. (2011) }\end{array}$ & G-CARBON \\
\hline \hline Forest lands & -244 & -107 & -31.0 & -5.5 \\
\hline Cropland soil & -17.9 & -3.0 & -2.7 & 51.4 \\
\hline Grassland & -13.2 & 0.2 & -3.1 & 0.6 \\
\hline Otherlands & -26.5 & -4.1 & -6.8 & -19.3 \\
\hline \hline Total & -302 & -114 & -44 & 27 \\
\hline
\end{tabular}

7 Table SM-9. Comparison to Hayes et al. results by ecosystem.

9 Note that the category otherlands contains the net effect of crop consumption and release in addition to NEE for all other ecosystem types.

11 The largest difference is in forest uptake. A portion of this difference may be due to 12 carbon dioxide fertilization effects. The sensitivity test described below with $\mathrm{Co} 2$ 13 fertilization increases the G-Carbon forest uptake to $180 \mathrm{GtC} / \mathrm{yr}$, which is closer to the 14 Hayes estimate. There is still a difference, however, which could be due to a number of 15 factors: even greater $\mathrm{CO} 2$ fertilization, larger nitrogen fertilization than assumed in G16 Carbon, or faster forest re-growth times.

\section{3. Sensitivity Test Details}

\section{$18 \quad 3.1$. Sensitivity Test Results}

19 The absolute change in carbon release (positive numbers indicate net carbon transfer

20 from the terrestrial system) for a range of sensitivity tests. 


\begin{tabular}{|c|c|c|c|c|c|}
\hline Scenario & \begin{tabular}{|c|} 
Total 1700- \\
2000
\end{tabular} & \begin{tabular}{|} 
Total 1850- \\
2000
\end{tabular} & $\begin{array}{c}\text { Total 2000- } \\
2100\end{array}$ & $\begin{array}{c}\text { Average } \\
1980-1989\end{array}$ & $\begin{array}{c}\text { Average } \\
1990-1999\end{array}$ \\
\hline & \multicolumn{3}{|c|}{$\mathrm{GtC}$} & \multicolumn{2}{|c|}{$\mathrm{GtC} / \mathrm{yr}$} \\
\hline Central Scenario & 251 & 210 & -66 & 1.3 & 0.8 \\
\hline \multicolumn{6}{|l|}{ Land-Use History } \\
\hline No Shifting Cultivation, Primary Land Priority & 254 & 211 & -72 & 1.3 & 0.7 \\
\hline No Shifting Cultivation, Secondary Land Priority & 245 & 204 & -60 & 1.3 & 0.8 \\
\hline Shifting Cultivation, Primary Land Priority & 258 & 216 & -77 & 1.4 & 0.9 \\
\hline Shifting Cultivation, Secondary Land Priority & 248 & 207 & -56 & 1.3 & 0.8 \\
\hline \multicolumn{6}{|l|}{ Carbon Density \& NPP Assumptions } \\
\hline All forest $\mathrm{C}$ densities based on CASA model & 340 & 286 & -88 & 2.0 & 1.3 \\
\hline Non-boreal forest $\mathrm{C}$ densities based on VEGAS model & 205 & 176 & -60 & 1.1 & 0.7 \\
\hline Non-boreal forest C densities based on CESM model & 236 & 204 & -54 & 1.6 & 1.0 \\
\hline CESM soil C densities for all available ecosystems & 212 & 170 & -74 & 1.0 & 0.5 \\
\hline CESM soil C densities for organic soils & 236 & 189 & -73 & 1.1 & 0.6 \\
\hline Tropical forest $\mathrm{C}$ densities from Harris et al. & 224 & 186 & -59 & 1.1 & 0.6 \\
\hline \multicolumn{6}{|l|}{ Cropland And Pasture } \\
\hline Cropland with grassland $\mathrm{C}$ values & 194 & 164 & -49 & 1.1 & 0.6 \\
\hline
\end{tabular}

Pasture with grassland $\mathrm{C}$ values

$225 \quad 185$

$-71$

1.1

0.6

Land-Use Change Carbon Disturbance

$5 \%$ soil loss to atmosphere from cropland and pasture under LUC

$50 \%$ litter loss to atmosphere from all forest under

LUC

No soil loss from grassland and shrubland under LUC $10 \%$ higher soil loss to atmosphere under LUC

No soil loss to atmosphere under LUC

Carbon Box Flow

Forest NPP to veg flow $25 \%$ higher

Forest NPP to veg flow $25 \%$ lower

Forest NPP $100 \%$ to vegetation

Pasture/grass/shrubland NPP to veg flow $25 \%$ higher

Pasture/grass/shrubland NPP to veg flow $25 \%$ lower

Crop NPP to litter flow $40 \%$

|

\begin{tabular}{l|l|l|l|l} 
& \\
& & & & \\
0.8
\end{tabular}

Other

No wetlands

Rapid tropical forest growth

Slow forest growth

No Forest Nitrogen Feedback

Feedbacks

CO2 Concentration (Beta) Feedback

Respiration (Q10) Feedback

\begin{tabular}{|l|l|l|l|l|}
\hline 252 & 211 & -64 & 1.3 & 0.8 \\
\hline 251 & 210 & -66 & 1.3 & 0.8 \\
\hline 247 & 206 & -63 & 1.3 & 0.8 \\
\hline 274 & 230 & -70 & 1.4 & 0.8 \\
\hline 240 & 201 & -63 & 1.3 & 0.8 \\
\hline 248 & 207 & -70 & 1.2 & 0.7 \\
\hline 255 & 214 & -59 & 1.4 & 0.9 \\
\hline 239 & 198 & -76 & 1.2 & 0.6 \\
\hline 251 & 210 & -66 & 1.3 & 0.8 \\
\hline 252 & 211 & -65 & 1.3 & 0.8 \\
\hline 258 & 216 & -72 & 1.2 & 0.7 \\
\hline 246 & 196 & -73 & 1.1 & 0.6 \\
\hline 249 & 207 & -68 & 1.2 & 0.7 \\
\hline 255 & 214 & -60 & 1.3 & 0.9 \\
\hline 262 & 221 & -57 & 1.6 & 1.1 \\
\hline \multicolumn{5}{|l|}{} \\
\hline
\end{tabular}

2 Table SM-10. Sensitivity test results (absolute values).

3

4 The above results presented as a percentage of the central model result in Table SM-11.

5 The magnitude of relative differences from the central result is indicated by background

6 color. 


\begin{tabular}{|c|c|c|c|c|c|}
\hline Scenario & \begin{tabular}{|c|} 
Total \\
$1700-2000$
\end{tabular} & $\begin{array}{c}\text { Total } \\
1850-2000\end{array}$ & \begin{tabular}{c|} 
Total \\
$2000-2100$
\end{tabular} & $\begin{array}{c}\text { Average } \\
1980-1989\end{array}$ & $\begin{array}{l}\text { Average } \\
1990-1999\end{array}$ \\
\hline \multicolumn{6}{|l|}{ Land-Use History } \\
\hline No Shifting Cultivation, Primary Land Priority & $101 \%$ & $100 \%$ & $109 \%$ & $101 \%$ & $92 \%$ \\
\hline No Shifting Cultivation, Secondary Land Priority & $98 \%$ & $97 \%$ & $91 \%$ & $101 \%$ & $95 \%$ \\
\hline Shifting Cultivation, Primary Land Priority & $103 \%$ & $103 \%$ & $117 \%$ & $105 \%$ & $109 \%$ \\
\hline Shifting Cultivation, Secondary Land Priority & $99 \%$ & $98 \%$ & $86 \%$ & $104 \%$ & $102 \%$ \\
\hline \multicolumn{6}{|l|}{ Carbon Density \& NPP Assumptions } \\
\hline CASA model forest C densities (not soil) & $135 \%$ & $136 \%$ & $134 \%$ & $158 \%$ & $163 \%$ \\
\hline VEGAS model non-boreal forest C densities (not soil) & $82 \%$ & $84 \%$ & $91 \%$ & $88 \%$ & $85 \%$ \\
\hline CESM model non-boreal forest C densities (not soil) & $94 \%$ & $97 \%$ & $83 \%$ & $122 \%$ & $130 \%$ \\
\hline $\begin{array}{l}\text { CESM model soil C densities for all ecosystems } \\
\text { available }\end{array}$ & $84 \%$ & $81 \%$ & $112 \%$ & $74 \%$ & $62 \%$ \\
\hline $\begin{array}{l}\text { CESM model soil C densities for ecosystems with } \\
\text { organic soils }\end{array}$ & $94 \%$ & $90 \%$ & $111 \%$ & $85 \%$ & $75 \%$ \\
\hline $\begin{array}{l}\text { Harris et al. Vegetation and litter C densities for tropical } \\
\text { forests }\end{array}$ & $89 \%$ & $88 \%$ & $90 \%$ & $85 \%$ & $76 \%$ \\
\hline
\end{tabular}

\section{Cropland And Pasture}

Cropland with grassland $\mathrm{C}$ values

Pasture with grassland $\mathrm{C}$ values

\begin{tabular}{|c|c|c|c|c|}
\hline $77 \%$ & $78 \%$ & $74 \%$ & $81 \%$ & $79 \%$ \\
\hline $89 \%$ & $88 \%$ & $107 \%$ & $86 \%$ & $81 \%$ \\
\hline
\end{tabular}

\section{Land-Use Change Carbon Disturbance}

\begin{tabular}{|c|c|c|c|c|c|}
\hline $\begin{array}{l}5 \% \text { soil loss to atmosphere from cropland and pasture } \\
\text { under LUC }\end{array}$ & $100 \%$ & $100 \%$ & $98 \%$ & $101 \%$ & $101 \%$ \\
\hline $50 \%$ litter loss to atmosphere from all forest under LUC & $100 \%$ & $100 \%$ & $100 \%$ & $99 \%$ & $101 \%$ \\
\hline No soil loss from grassland and shrubland under LUC & $98 \%$ & $98 \%$ & $96 \%$ & $101 \%$ & $103 \%$ \\
\hline $10 \%$ higher soil loss to atmosphere under LUC & $109 \%$ & $109 \%$ & $107 \%$ & $106 \%$ & $100 \%$ \\
\hline No soil loss to atmosphere under LUC & $96 \%$ & $96 \%$ & $95 \%$ & $97 \%$ & $101 \%$ \\
\hline \multicolumn{6}{|l|}{ Carbon Box Flow } \\
\hline Forest NPP to veg flow $25 \%$ higher & $99 \%$ & $98 \%$ & $106 \%$ & $96 \%$ & $92 \%$ \\
\hline Forest NPP to veg flow $25 \%$ lower & $102 \%$ & $102 \%$ & $90 \%$ & $105 \%$ & $110 \%$ \\
\hline Forest NPP $100 \%$ to vegetation & $95 \%$ & $94 \%$ & $115 \%$ & $91 \%$ & $78 \%$ \\
\hline Pasture/grass/shrubland NPP to veg flow $25 \%$ higher & $100 \%$ & $100 \%$ & $101 \%$ & $100 \%$ & $100 \%$ \\
\hline Pasture/grass/shrubland NPP to veg flow $25 \%$ lower & $100 \%$ & $100 \%$ & $99 \%$ & $100 \%$ & $100 \%$ \\
\hline Crop NPP to litter flow $40 \%$ & $103 \%$ & $103 \%$ & $109 \%$ & $94 \%$ & $88 \%$ \\
\hline \multicolumn{6}{|l|}{ Other } \\
\hline No wetlands & $98 \%$ & $93 \%$ & $111 \%$ & $86 \%$ & $79 \%$ \\
\hline Rapid tropical forest growth & $99 \%$ & $99 \%$ & $104 \%$ & $96 \%$ & $91 \%$ \\
\hline Slow forest growth & $101 \%$ & $102 \%$ & $91 \%$ & $104 \%$ & $109 \%$ \\
\hline No Forest Nitrogen Feedback & $104 \%$ & $105 \%$ & $86 \%$ & $121 \%$ & $139 \%$ \\
\hline \multicolumn{6}{|l|}{ Feedbacks } \\
\hline CO2 Concentration (Beta) Feedback & $57 \%$ & $55 \%$ & $426 \%$ & $-6 \%$ & $-102 \%$ \\
\hline Respiration (Q10) Feedback & $107 \%$ & $109 \%$ & $-11 \%$ & $126 \%$ & $177 \%$ \\
\hline
\end{tabular}

1 Table SM-11. Sensitivity test results (as \% from central scenario). 


\subsection{NPP and Carbon Values for Sensitivity Tests}

3 Equilibrium carbon data was provided by three detailed ecosystem models: CASA 4 (van der Werf et al. 2010), CESM (Lawrence et al. 2011, Lawrence et al. 2012), and 5 VEGAS models (Zeng et al. 2005a, 2005b). This is a sample of convenience, when contacted, these groups provided the gridded pre-industrial carbon and NPP data needed to calibrate the G-Carbon model. For consistency, we used both NPP and equilibrium carbon contents from each model to calibrate forest ecosystems in G-Carbon as described below.

Above ground forest carbon density is not directly available from most ecosystem model outputs, instead only total vegetation carbon density (for forested and non-forested portions of the cell) by grid cell is provided. This means that forest carbon density must be inferred from model outputs, given that, in general, grid cells are generally partitioned between multiple ecosystem types. In the case of CASA, vegetation is internally represented as forested and herbaceous, in the case of VEGAS between four PFTs, and in the case of CESM between multiple ecosystem types.

The following procedure was used to infer forest carbon density for purposes of conducting sensitivity tests. In all cases, data is estimated using a pre-industrial equilibrium spin-up supplied by each modeling group, where vegetation has reached its equilibrium value. Note that, for CASA, the spin-up period is for 1946 .

For CASA, based on the percentage of tree-cover and vegetation-cover, grid cells were categorized into separate classes, separated into $10 \%$ increments of forest cover. The forest carbon density was taken to be the average of the two bins with the highest fractional forest cover that included at least $10 \%$ of total forested cells, filtering by cells that were designated as forest cells in the CASA vegetation map. Density values were obtained for vegetation, litter, and NPP by dividing total carbon by the total tree-covered area of the cells used to obtain densities; the total soil carbon was divided by the total vegetation-covered area of the cells to obtain the density.

Forest carbon densities for CESM were processed in a similar fashion. In this case, the total carbon in forested cells estimated in this manner was greater than the total carbon in the original CESM output data in several regions. The largest bias was in the USA, Africa, Latin America, and Southeast Asia. This could be because the forested portion of cells with a high forest cover in these regions had higher vegetation density than cells with lower fractional forest cover. The average carbon density values in these regions were reduced to be consistent with the total vegetation carbon in forested cells. The carbon density was set so that total forest vegetation carbon was equal to total aboveground vegetation carbon from the CESM data times the fraction of forest vegetation to total above ground vegetation in each region from the default G-CARBON dataset.

For VEGAS a similar process occurred, except that tree-cover and vegetation-cover grids were not available for the data. Vegetation type grids were used instead, and the same percent cover classes were created based on percent forest PFT, and percent vegetation of any type. The CASA vegetation map was used to filter out cells that are not 
1 forest cells in the CASA dataset. This was done because the VEGAS forest PFT category

2 represents a broad range of woody vegetation, and we wanted to restrict our sensitivity

3 test to areas that would be considered forest in the other datasets. To obtain forest

4 vegetation carbon as comparable as possible to the other datasets, we also reduced the

5 estimated value by the fraction of forest vegetation to total above ground vegetation in 6 each region from the default G-CARBON dataset.

For a majority of regions, especially in tropical areas, the average non-boreal forest carbon densities from Carnegie-Ames-Stanford Approach (CASA) Project are higher than the values used in the G-CARBON central scenario (Potter, 2012). If CASA regional boreal and non-boreal forest NPP and C densities are used for forest in GCARBON, the global cumulative emissions for the period 1700-2000 are $89 \mathrm{GtC}$ higher than in the central scenario, an increase of $35 \%$. If GCAM central model carbon densities are used for all ecosystems (except crops and wetlands), total emissions are $23 \mathrm{GtC}(9 \%)$ higher. If only the GCAM boreal forest and non-boreal forest carbon density values are used, emissions are $14 \mathrm{GtC}(5.6 \%)$ higher. If non-boreal forest $\mathrm{C}$ densities from the Vegetation-Global-Atmosphere-Soil (VEGAS) Terrestrial Carbon Cycle Model are used, 1700-2000 emissions are $16.4 \mathrm{GtC}(6.5 \%)$ higher. For many regions, VEGAS non-boreal forest vegetation $\mathrm{C}$ densities are lower than the central values, but soil $\mathrm{C}$ is higher. Emissions from non-boreal forest are actually $19.8 \mathrm{GtC}$ lower than in the central model; emissions from the croplands and pasture that these forests are converted to, however, are $16.8 \mathrm{GtC}$ and $19.4 \mathrm{GtC}$ higher respectively. Almost all of the increased emissions come from tropical areas. Vegetation C estimates from the Community Earth System Model (CESM) are very high in tropical areas, and very low in some non-tropical areas. CESM soil C estimates do not include organic $\mathrm{C}$; for non-boreal forest, for most regions, these estimates are slightly lower than the central estimates used. If non-boreal forest NPP and carbon densities from CESM are used, 1700-2000 emissions are 20.4 GtC (8.1\%) higher. The higher emissions are nearly all released from non-boreal forest, as $78 \%$ of forest vegetation goes directly to the atmosphere during LUC.

If CESM mineral soil $\mathrm{C}$ is used for all ecosystems, total emissions are $40.3 \mathrm{GtC}$ (15.9\%) lower. Cropland releases are $42.7 \mathrm{GtC}$ lower (78\% less) than emissions in the default scenario over this period. Secondary forest uptake is $15.8 \mathrm{GtC}$ greater (44\% higher) than in the central scenario. If CESM mineral soil C is used only for ecosystems with high organic $\mathrm{C}$ contents (boreal forest, tundra, all wetlands, and, indirectly, pasture), emissions are $21.3 \mathrm{GtC}(8.4 \%)$ lower. Pasture takes up 12.4 more $\mathrm{GtC}$ than it does in the central scenario, an increase of $106 \%$. Similarly, cropland releases 13.9 GtC $(25 \%)$ less than in the central scenario. Because peat does not build up, high latitude wetlands take up almost no carbon, whereas in the central scenario they take up $8.3 \mathrm{GtC}$ over this period. Low latitude wetlands release $3.5 \mathrm{GtC}$. Secondary non-boreal forest uptake is 7.2 $\mathrm{GtC}(24 \%)$ higher than in the central scenario.

40

The assumptions used in the tropical forest sensitivity test are provided below: 


\begin{tabular}{lcc} 
Region & $\begin{array}{c}\text { Vegetation Density } \\
\text { Harris et al. } \\
\left(\mathbf{k g C} / \mathbf{m}^{\mathbf{2}}\right) \\
\text { Default } \\
\text { Value }\end{array}$ \\
\hline Africa & 9.3 & 16.6 \\
Latin America & 11.2 & 17.2 \\
Southeast Asia & 14.9 & 17.1 \\
India & 10.4 & 15.5
\end{tabular}

Table SM-12. Vegetation carbon density values used for tropical forest sensitivity test.

The Harris et al. values are smaller than the default values, resulting in lower estimates of LUC emissions. We note, however, that these values appear to be for all forests: if substantial areas of secondary forest are included, these values could be biased low in their use here as estimates of primary (undisturbed) forest carbon density. The Harris et al. (2012) values are similar to those derived by Baccini et al. (2012), except for their "Tropical Asia" value $\left(11.6 \mathrm{kgC} / \mathrm{m}^{2}\right)$ which is lower than the values above. ${ }^{1}$ Baccini et al. (2012) also show estimates for forests overall, and forest where "deforestation took place". In many cases these values are quite different, highlighting the issue of heterogeneity.

\subsection{Land-Use Change Carbon Disturbance}

The fate of carbon under LUC is not well-constrained. Some of the carbon initially held on sites that are cleared or harvested is released to the atmosphere immediately, and some is released gradually. In the G-CARBON central scenario, when an area used as cropland or pasture is changed to a different land-use, all of the soil carbon stays in the soil; for all other land-uses, $5 \%$ of the soil carbon is released to the atmosphere immediately. In a sensitivity experiment, if $5 \%$ of the soil carbon is immediately released from cropland and pasture when these land-uses change, over 1700-2000 an additional $0.5 \mathrm{GtC}$ is released, an increase of $0.2 \%$ above the central scenario.

In the central scenario, for all land-uses when LUC occurs, $75 \%$ of the litter carbon is immediately released to the atmosphere and $25 \%$ stays as litter carbon. In a sensitivity experiment, forest litter carbon parameters were set so that when boreal or non-boreal forest is changed to another land-use, only $50 \%$ of the litter carbon goes to the atmosphere immediately. Over the period 1700-2000 this has a very small effect, causing $0.7 \mathrm{GtC}$ less to be released, a decrease in emissions of $0.3 \%$ below the central scenario.

In a third sensitivity test, no grassland or shrubland soil carbon is immediately released during LUC. This has a slightly larger effect than the previous changes, causing the release of $4.7 \mathrm{GtC}$ less from 1700-2000 than the central scenario, a decrease of $1.9 \%$.

In a fourth test, for all land-uses, the immediate release of soil carbon during LUC is set $10 \%$ higher than the release for each corresponding land-use in the central scenario.

1 See also: http://blogs.nature.com/news/2012/12/scientists-publish-consensus-statement-ondeforestation-emissions.html/ 
1 This causes an additional release of $22.6 \mathrm{GtC}$ over the period 1700-2000, an increase in 2 emissions of $8.9 \%$.

3 In a fifth test, for all land-uses, no $\mathrm{C}$ is immediately released from the soil to the 4 atmosphere during LUC. $11.1 \mathrm{GtC}$ less is released over 1700-2100, a decrease of 4.4\%.

\subsection{Carbon Box Turnover-Time Sensitivities}

For non-boreal forest, the flow of carbon from NPP to vegetation are set for each region individually, in order to match turnover timescales in the literature. If each flow is increased by $25 \%$ of its value (e.g., a flow of $20 \%$ will increase to $25 \%$ ), and timescales decreased in order to maintain the same equilibrium carbon contents, 1700-2000 emissions are $3.7 \mathrm{GtC}(1.5 \%)$ lower; from $2000-2100$ there is $3.9 \mathrm{GtC}(5.8 \%)$ more uptake. If each flow is decreased by $25 \%$ of its value, $1700-2000$ emissions are $3.9 \mathrm{GtC}$ (1.5\%) higher, and from $2000-2100$ there is $6.7 \mathrm{GtC}(10 \%)$ less uptake. If all flows from NPP to vegetation are set to be $100 \%$ (e.g., no NPP directly to litter), $1700-2000$ emissions are $13 \mathrm{GtC}(5.1 \%)$ lower, and from $2000-2100$ there is $10 \mathrm{GtC}(15 \%)$ more uptake.

When the same $\pm 25 \%$ manipulations are performed on pasture, grassland, and shrubland of all regions simultaneously, resulting emissions changes are negligible.

If, for all regions, cropland flow from NPP to litter is reduced from $65 \%$ to $40 \%$, and flow to soil is increased from $15 \%$ to $40 \%, 1700-2000$ emissions are increased by 5.3 GtC (2.1\%). From 2000-2100 5.2 GtC more (7.7\%) is taken up.

\subsection{Other Forest Sensitivities}

If forest nitrogen fertilization is not included in the model, total emissions over 17002000 are $10.9 \mathrm{GtC}(4.3 \%)$ higher. In this case, there is less carbon uptake over the period 2000-2100 as well; 9.2 less GtC of carbon (13.6\%) is taken up.

Turnover timescales of forests are also highly uncertain. If the equilibrium carbon content is held steady, but the flows are adjusted so that the timescales of non-boreal forests of tropical regions are reduced by $17-33 \%$ (exact amounts depending on individual settings), total emissions over 1700-2000 are $2.9 \mathrm{GtC}$ (1.2\%) lower. Uptake over the period $2000-2100$ is $2.6 \mathrm{GtC}(3.9 \%)$ higher.

If the turnover timescales of all boreal and non-boreal forests are increased by $30 \%$, total emissions over $1700-2000$ are $3.5 \mathrm{GtC}(1.4 \%)$ higher. Uptake over the period 20002100 is $6.0 \mathrm{GtC}(8.9 \%)$ lower.

\subsection{Wetlands Sensitivity}

Wetland have two impacts on LUC emissions. First, as high carbon ecosystems, conversion of wetlands to other land-uses entails a direct loss of carbon. This component is included in the LUC emissions estimates presented in this paper. Also lost is the ongoing carbon sink represented by wetlands, particularly in mid to low latitudes. In a model simulation with no land-use change wetlands take up $19 \mathrm{GtC}$ from 1700-2000 and $5 \mathrm{GtC}$ from 2000-2100. (The slight decline in uptake rate is a consequence of the simple 
1 formulation of this model whereby all ecosystem approach some equilibrium, including 2 wetlands.) In the central model simulation above with land-use change the 1700-2000 3 uptake by wetlands is reduced to $10 \mathrm{GtC}$ due to conversion of wetlands to other uses.

4 This additional anthropogenic effect also contributes to increasing carbon dioxide in the 5 atmosphere. It is unclear if this component should be included in the definition of LUC 6 emissions.

If wetlands are not included as an ecosystem (only the ecosystems of SAGE and MODIS are included), 1700-2000 emissions are $6 \mathrm{GtC}$ (2.4\%) lower, and from 20002100 there is $6.9 \mathrm{GtC}(10 \%)$ more uptake. Note that this comparison includes a wetland sink in the core model and no wetland sink in the sensitivity test without wetlands.

There is a large uncertainty in these figures since wetland extent and characteristics are not well constrained. These illustrate, however, that the inclusion of wetland has a non-trivial impact on global carbon stocks.

\subsection{Temperature And Carbon Dioxide Feedback}

While climate feedbacks are not the primary focus of this paper, sensitivity tests that included climate and carbon dioxide feedbacks are included in the test suite so that the potential magnitude of climate feedback effects can be compared to the other sensitivity effects examined here.

Two feedbacks are included, a conventional beta feedback on NPP and a Q10 feedback on litter and soil carbon stocks, represented as shown in the Equations below.

$$
N P P=N P P_{0}\left(1+\beta \log \left(C_{C_{2}} / C_{0}\right)\right)
$$

$$
\tau=\tau_{0} / Q_{10}^{\left(\left(T-T_{0}\right) / 10\right)}
$$

Through the beta feedback, increasing carbon dioxide concentrations are assumed to increase net NPP of all ecosystems equally, except for cropland. Since cropland NPP is exogenously specified to match observed data, which includes any impact of any climate and $\mathrm{CO}_{2}$ concentration changes, we do not apply a $\mathrm{CO}_{2}$ concentration feedback for this ecosystem. Beta was taken to be equal to 0.6 for this sensitivity test. This value is somewhat arbitrary (a separate work will conduct a historical calibration experiment for these parameters), but this value is within the range found to be consistent with observation (Ricciuto et al. 2006). Historical $\mathrm{CO}_{2}$ concentrations from the MAGICC simple climate model (Wigley 1993), as used in GCAM, are used as input to this feedback equation.

Through the Q10 feedback, soil and liter turnover timescales are decreased as temperatures increase, representing increased heterotrophic respiration with temperature. For the simple sensitivity test assumed here, Q10 was taken to equal 2 for all litter carbon pools and 1.75 for soil carbon pools (since some soil carbon is thermally buffered from 
arbitrary, but is only used to give a sense of general magnitude of the potential effect.

2 Regional and ecosystem-specific historical temperature from 1870-2008 was taken from

3 Compo et al. (2011). This model-based reconstruction data set is used instead of

4 observationally-based reconstruction because, unlike observational data sets, this dataset

has uniform spatial coverage over time. This allows us to extract ecosystem-specific temperature trends for each region over time. Temperature trends in all regions after 2008 are taken from the MAGICC simple climate model.

These are sensitivity tests only. Feedbacks in the actual carbon-cycle almost certainty do not follow these simple functional forms. There is, however, not a consensus on the strength and nature of these feedbacks, so these simple functional forms are useful illustrating the potential impact of feedbacks. There are also observational constraints on feedbacks: for example the overall behavior of the carbon cycle must be consistent with the observed changes in carbon dioxide concentrations over time. In the illustrative sensitivity test performed here, carbon dioxide concentrations and historical temperature changes are exogenous and fixed.

\section{References}

Blodau, C. 2002. Carbon cycling in peatlands - a review of processes and controls. Environmental Reviews (10): 111-134.

Bridgham, S.D., J.P. Megonigal, J.K. Keller, N.B. Bliss, and C. Trettin, 2007: Wetlands. In: The First State of the Carbon Cycle Report (SOCCR): The North American Carbon Budget and Implications for the Global Carbon Cycle. A Report by the U.S. Climate Change Science Program and the Subcommittee on Global Change Research [King, A.W., L. Dilling, G.P. Zimmerman, D.M. Fairman, R.A. Houghton, G. Marland, A.Z. Rose, and T.J. Wilbanks (eds.)]. National Oceanic and Atmospheric Administration, National Climatic Data Center, Asheville, NC, USA, pp. 139-148.

Buchanan, A. H. and S. B. Levine (1999). "Wood-based building materials and atmospheric carbon emissions." Environmental Science \& Policy 2(6): 427-437.

Compo, G. P., J. S. Whitaker, P. D. Sardeshmukh, N. Matsui, R. J. Allan, X. Yin, B. E. Gleason, R. S. Vose, G. Rutledge, P. Bessemoulin, S. Bronnimann, M. Brunet, R. I. Crouthamel, A. N. Grant, P. Y. Groisman, P. D. Jones, M. C. Kruk, A. C. Kruger, G. J. Marshall, M. Maugeri, H. Y. Mok, O. Nordli, T. F. Ross, R. M. Trigo, X. L. Wang, S. D. Woodruff and S. J. Worley (2011). "The Twentieth Century Reanalysis Project." Quarterly Journal of the Royal Meteorological Society 137(654): 1-28.

Don, A., J. Schumacher, et al. (2011). "Impact of tropical land-use change on soil organic carbon stocks - a meta-analysis." Global Change Biology 17(4): 1658-1670.

Emanuel, W.R., G.G. Killough, W.M. Post, and H.H. Shugart, 1984. Modeling terrestrial ecosystems in the global carbon cycle with shifts in carbon storage capacity by land-use change. Ecology, 63(3): 970-983.

40 FAOSTAT Production. (2012, February 23). Retrieved April 3, 2012, from 41 http://faostat.fao.org/site/339/default.aspx

42 Guo, L. B. and R. M. Gifford (2002). "Soil carbon stocks and land use change: a meta analysis." 43 Global Change Biology 8(4): 345-360. 
Harvey, L.D.D., 1989. Effect of model structure on the response of terrestrial biosphere models to

$2 \mathrm{CO} 2$ and temperature increases. Global Biogeochemical Cycles, 3,2, 137.

3 Hay, R. K. M. and J. R. Porter, 2006. The Physiology of Crop Yield. Second edition. Oxford:

4 Blackwell Publishing (2006), pp. 314, £34.99(paperback). ISBN 1-4051-0859-2.

5 doi:10.1017/S0014479707005595

6 Hayes, D. J., D. P. Turner, et al. (2012). "Reconciling estimates of the contemporary North

7 American carbon balance among terrestrial biosphere models, atmospheric inversions, and a new

8 approach for estimating net ecosystem exchange from inventory-based data." Global Change

9 Biology 18(4): 1282-1299.

10 Houghton, R.A., 1999. The annual net flux of carbon to the atmosphere from changes in land use 1850-1990. Tellus, 51B: 298-313

Houghton, R.A., and J.L. Hackler, 1995. Continental scale estimates of the biotic carbon flux from land cover change: 1850-1980 (R.C. Daniels, editor). ORNL/CDIAC-79, NDP-050. Carbon Dioxide Information Analysis Center, Oak Ridge National Laboratory, U.S. Department of Energy, Oak Ridge, Tennessee.

Hurtt, G.C., L.P. Chini, S. Frolking, R.A. Betts, J. Feddema, G. Fischer, J.P. Fisk, K. Hibbard, R.A. Houghton, A. Janetos, C.D. Jones, G. Kindermann, T. Kinoshita, K. Klein Goldewijk, K. Riahi, E. Shevliakova, S. Smith, E. Stehfest, A. Thomson, P.Thornton, D.P. van Vuuren, Y.P. Wang, 2011. Harmonization of land-use scenarios for the period 1500-2100: 600 years of global gridded annual land-use transitions, wood harvest, and resulting secondary lands. Climate Change (109): 117-161.

Jain, A.K. and X. Yang (2005): Modeling the Effects of Two Different Land Cover Change Data Sets on the Carbon Stocks of Plants and Soils in Concert With CO2 and Climate Change, Global Biogeochemical Cycles, 19, GB2015, doi:10.1029/2004GB002349.

King, A.W., L. Dilling, G.P. Zimmerman, D.M. Fairman, R.A. Houghton, G. Marland, A.Z. Rose, and T.J. Wilbanks (eds.) (2007) The First State of the Carbon Cycle Report (SOCCR): The North American Carbon Budget and Implications for the Global Carbon Cycle. A Report by the U.S. Climate Change Science Program and the Subcommittee on Global Change Research (National Oceanic and Atmospheric Administration, National Climatic Data Center, Asheville, NC, USA) 242 pp.

King, A.W., W.M. Post, and S.D. Wullschleger, 1997. The potential response of terrestrial carbon storage to changes in climate and atmospheric CO2. Climatic Change, 35: 199-227.

Kyle et al., 2011. GCAM 3.0 Agriculture and Land Use: Data Sources and Methods. Available at: http://wiki.umd.edu/gcam/

Lawrence, D.M., K.W. Oleson, M.G. Flanner, P.E. Thornton, S.C. Swenson, P.J. Lawrence, X. Zeng, Z.-L. Yang, S. Levis, K. Sakaguchi, G.B. Bonan, and A.G. Slater (2011) Parameterization improvements and functional and structural advances in version 4 of the Community Land Model. J. Adv. Model. Earth Sys., 3, DOI: 10.1029/2011MS000045.

Lawrence, P.J., J.J. Feddema, G.B. Bonan, G.A. Meehl, B.C. O’Neill, S. Levis, D.M. Lawrence, K.W. Oleson, E. Kluzek, K. Lindsay, and P.E. Thornton, 2012. Simulating the biogeochemical and biogeophysical impacts of transient land cover change and wood harvest in the Community Climate System Model (CCSM4) from 1850 to 2100. Journal of Climate, doi: 10.1175/JCLI-D$11-00256.1$

Lobell, D. B., J. A. Hicke, et al. (2002). "Satellite estimates of productivity and light use efficiency in United States agriculture, 1982-98." Global Change Biology 8(8): 722-735.

Luo, Z. K., E. L. Wang, et al. (2010). "Soil carbon change and its responses to agricultural practices in Australian agro-ecosystems: A review and synthesis." Geoderma 155(3-4): 211-223. 
1 Mitchell, B.R. (1975). European Historical Statistics, 1750-1970. Abridged Ed. Columbia Univ 2 Pr.

3 Mitchell, B.R. (1988). British Historical Statistics. University Press, Cambridge.

4 Mitchell, B.R. (2007a). International Historical Statistics: Africa, Asia and Oceania, 1750-2005

$5 \quad$ ( $1^{\text {st }}$ ed.). Palgrave Macmillan.

6 Mitchell, B.R. (2007b). International Historical Statistics: The Americas, 1750-2005 (1 ${ }^{\text {st }}$ ed.).

7 Palgrave Macmillan.

8 Mitchell, B.R. (2007c). International Historical Statistics: Europe, 1750-2005 (1 ${ }^{\text {st }}$ ed.). Palgrave 9 Macmillan.

10 Murty, D., M. U. F. Kirschbaum, et al. (2002). "Does conversion of forest to agricultural land 11 change soil carbon and nitrogen? a review of the literature." Global Change Biology 8(2): 10512123

13 NASA Land Processes Distributed Active Archive Center (LP DAAC). MODIS 12C1.

14 USGS/Earth Resources Observation and Science (EROS) Center, Sioux Falls, South Dakota. 152001.

16 Potter, C., S. Klooster, V. Genovese, 2012. Net primary production of terrestrial ecosystems from 172000 to 2009. Climatic Change, doi: 10.1007/s10584-012-0460-2.

18 Sinclair, T.R, 1998. Historical changes in harvest index and crop nitrogen accumulation. Crop 19 Science, Volume 38, Issue 3.

20 Six, J. and J.D. Jastrow, 2002. Soil Organic Matter Turnover. In R. Lal (Ed.). Encyclopedia of 21 Soil Science, Marcel Dekker, NY. Pp 936-942.

22 Smith, Steven. J. (2013) "Historical And Future Carbon Emissions From Croplands." Global 23 Biogeochemical Cycles, Submitted.

24 Thomson, A.M, R.C. Izaurralde, S.J. Smith, and L.E. Clarke, 2008. Integrated estimates of 25 global terrestrial carbon sequestration. Global Environmental Change, 18, 192-203.

26 Trant, G.I. (1999). Historical Statistics of Canada Section M: Agriculture (No. 1983001). 27 Statistics Canada.

28 USDA NASS - Statistics By Subject. (n.d.). USDA National Agricultural Statistics Service.

29 Retrieved April 3, 2012, from http://www.nass.usda.gov/Statistics_by_Subject/index/php

30 Van der Werf, G.R., D.C. Morton, R.S. DeFries, J.G.J. Olivier, P.S. Kasibhatla, R.B. Jackson, 31 G.J. Collatz, and J.T. Randerson (2009) CO2 emissions from forest loss. Nature Geoscience, 2: $32 \quad 737-738$.

33 Wigley, T. M. L. 1993. Balancing the Carbon Budget - Implications for Projections of Future 34 Carbon-Dioxide Concentration Changes Tellus 45B, 409-425.

35 Winjum, J. K., S. Brown, et al. (1998). "Forest harvests and wood products: Sources and sinks of 36 atmospheric carbon dioxide." Forest Science 44(2): 272-284.

37 Zeng, N., A. Mariotti, and P. Wetzel (2005a) Terrestrial mechanisms of interannual CO2 38 variability, Global Biogeochemical Cycles, 19, GB1016, doi:10.1029/2004GB002273.

39 Zeng, N., H. Qian, C. Roedenbeck, and M. Heimann (2005b) Impact of 1998-2002 midlatitude 40 drought and warming on terrestrial ecosystem and the global carbon cycle. Geophys. Res. Lett., 4132 , L22709, doi:10.1029/2005GL024607.

42 